UDC 61

\title{
THE CORRELATION BETWEEN TRAINING AND EXPERIENCE WITH SELF EFFICACY IN VOLUNTEER TO DOING FIRST AID FOR VICTIMS ON TRAFFIC ACCIDENT IN MALANG
}

\author{
Wahyuningsih Indri*, Andarini Sri, Utami Yulian Wiji \\ Faculty of Medicine, University of Brawijaya, Indonesia \\ *E-mail: ns.indri08@gmail.com
}

\begin{abstract}
Traffic accidents increase morbidity and mortality requiring the development of emergency services both pre-hospital and in-hospital through the establishment of an Integrated Emergency Response System (SPGDT), one of which is the Public Safety Center (PSC). Volunteers are part of organizing the PSC. However, volunteers said that when giving first aid to KLL victims it is often not possible to have confidence in relation to self-efficacy. The objective of this study is to explain about the correlation of training and experience with self efficacy in voluteer to doing first aid for victims o traffic accidents in Malang. This research was conducted in 4 traffic volunteer communities in Malang, namely PPMR, RJT, PSC and Pakem, totaling 107 respondents. The Spearman correlation test showed that there was a significant relationship between training and experience $(p=0,000)$ with self-efficacy with $(p$ $<0.05$ ). Linear regression analysis showed the results that the variables most related to volunteer self-efficacy in performing first aid for KLL victims were experiences with $\beta=0.407$. The conclusion of this study is a correlation between training and experience with volunteer self-efficacy in carrying out first aid for KLL victims. The factors that most influence volunteer self-efficacy are experience in conducting first aid for KLL victims.
\end{abstract}

\section{KEY WORDS}

Self-efficacy, volunteer, training, experience, first aid.

Traffic accidents caused 1.25 million deaths globally in 2013. The highest rates of traffic accidents were in low and middle income countries, namely 19.5 and 12.7 per 100,000 human populations. It is estimated that KLL will be the seventh cause of mortality in the world in 2030 (WHO, 2013). WHO (2015) states that in Indonesia there were 38,279 victims died because of KLL with details of 105 people / day and 4 people / hour. In the city of Malang, there were $623 \mathrm{KLL}$ cases in 2012 with 140 deaths and 796 injured (Marsaid et al, 2013).

Regarding this, a Regulation of the Minister of Health of the Republic of Indonesia No. 19 of 2016 through the establishment of an integrated and integrated handling system involving various parties from various multidisciplinary professions by utilizing 119 call center services called the Integrated Emergency Response System (SPGDT) consisting of the National Command Center located in The Ministry of Health in Jakarta and the Public Safety Center (PSC) based in the Regency / City. The PSC consists of coordinators, health workers, call center operators and other personnel. The Malang city PSC has 13 members consisting of 11 volunteers, 1 nurse and 1 midwife. Malang City PSC involves the role of ordinary people, namely through collaboration with volunteers. Volunteers say they often feel disbelief when carrying out first aid actions for KLL victims because of limited knowledge and skills.

Volunteer mistrust in carrying out first aid for KLL victims is possible due to selfefficacy. Huang and Peng (2014) say that self-efficacy in performing first aid is influenced by competencies which include knowledge about first aid, training, information media, general knowledge about health, and experience injuries. In line with this, Kandakai and King (2013) say that training is the most effective indicator of improving self-efficacy when carrying out first aid measures. Based on the exposure to the problem above, researchers wanted to find out more about the relationship of training and experience with volunteers' self-efficacy in carrying out first aid for KLL victims in Malang. 


\section{METHODS OF RESEARCH}

This study used a cross sectional correlative analytic research design study. The population in this study were all members of the traffic volunteer community in Malang, namely a number of 4 communities. The number of membership for each community is RJT with 40 people, PPMR with 39 people, PSC with 8 people and Pakem with 20 people. So that the total population in this study was 107 people. In this study, researchers used a nonprobability sampling technique for total sampling with sample inclusion criteria, among others: Malang traffic volunteers, registered and had a sign of volunteer members, had attended training, were willing to become respondents.

Table 1 - Distribution of Respondent

\begin{tabular}{cccc}
\hline Variable & Mean & Median & Min - Maks \\
\hline Age & 34,78 & 35 & $20-54$ \\
Period of volunteer & 2,62 & 3 & $1-5$ \\
Training & 2,47 & 2 & $1-4$ \\
Experience & 19,76 & 20 & $15-24$ \\
\hline
\end{tabular}

Based on table 1, the median value of the respondents of the traffic volunteers in this study was 35 years, the duration of volunteering was 3 years, the training was 2 times and the experience of helping KLL victims was 20.

\section{RESULTS OF STUDY}

Table 2 - Self Efficacy of Respondent

\begin{tabular}{ccc}
\hline Variable & Mean \pm SD & $95 \% \mathrm{Cl}$ \\
\hline Self Efficacy & $24,89 \pm 5,975$ & $23,74-26,03$ \\
\hline
\end{tabular}

Based on table 2, the average value of the traffic volunteer self-efficacy score in this study was 24.89 with a standard deviation of 5.975 and from interval estimates it can be concluded that $95 \%$ are believed to be an average score of self-efficacy between 23.7426.03.

Table 3 - The Correlation Between Training and Self Efficacy

\begin{tabular}{ll}
\hline & Self Efficacy \\
\hline Training & $r=0,945$ \\
\cline { 2 - 2 } & $p=0,000^{\star}$ \\
\hline
\end{tabular}

*significant: $p$ value $<0,05$

The results of statistical tests on training and self-efficacy variables obtained $p=0,000$ $(\alpha<0.05)$, it can be concluded that there is a significant relationship between volunteer selfefficacy training in conducting first aid for KLL victims in Malang. The relationship between volunteer self-efficacy training showed a very strong relationship $(r=0.945)$ and a positive pattern which means that the higher or often the frequency of training, the higher the selfefficacy of volunteers in carrying out first aid for KLL victims. The training studied in this study was the experience of volunteers in conducting heart massage, wound management and bleeding, shock and bone management. The type of training that is most often followed is heart massage and bleeding control.

Table 3 - The Correlation Between Experience and Self Efficacy

\begin{tabular}{cc}
\hline & Self Efficacy \\
\hline \multirow{2}{*}{ Experience } & $\mathrm{r}=0,913$ \\
\cline { 2 - 2 } & $\mathrm{p}=0,000^{\star}$ \\
\hline
\end{tabular}

*significant: $p$ value $<0,05$ 
The results of statistical tests on the experience and self-efficacy variables obtained $p$ $=0,000(\alpha<0.05)$, it can be concluded that there was a significant relationship between volunteer self-efficacy in conducting first aid for KLL victims in Malang. The relationship between experience and volunteer self-efficacy showed a very strong relationship $(r=0.913)$ and a positive pattern which means that the higher or often the frequency of first aid for KLL victims is the higher the voluntary self-efficacy in carrying out first aid to KLL victims. The experience of the volunteers studied in this study included experience in securing victims, securing the location of the incident, providing breathing assistance, carrying out life threatening actions, controlling bleeding and contacting the ambulance. The results of highfrequency experience studies experienced by volunteers include securing victims, location, controlling bleeding and calling for an ambulance.

Table 4 - Selection of Bivariat Variable

\begin{tabular}{cc}
\hline Variable & $P$ Value \\
\hline Training & $0,000^{*}$ \\
Experience & $0,000^{*}$ \\
\hline
\end{tabular}

*include $(p<0,25)$.

The results of table 4 show the training and experience variables have a value of $p$ $<0.25$. Furthermore, for these variables will be included in multivariate model.

Table 5 - Multivariat Model

\begin{tabular}{ccc}
\hline Variable & \multicolumn{3}{c}{ Model of Multivariat } \\
\cline { 2 - 3 } & $\mathrm{P}$ & Coef $B$ \\
\hline Training & 0,000 & 2,130 \\
Experience & 0,000 & 0,777 \\
\hline
\end{tabular}

Based on table 5, the results show that there are no variables that have $p$ value $>0.05$, so there are no variables released from modeling. Thus the modeling results obtained 2 of the most dominant variables related to volunteer self-efficacy in carrying out first aid for KLL victims in Malang, namely training and experience.

Table 6 - Linier Regression

\begin{tabular}{|c|c|c|c|c|c|}
\hline Model & B & Beta & $\mathrm{R}$ & R2 & $P$ \\
\hline Constant & $-2,151$ & & & \multirow{3}{*}{$0,9550,9130,000$} & \\
\hline Training & 2,130 & 0,377 & & & \\
\hline Experience & 0,777 & 0,407 & & & \\
\hline
\end{tabular}

The $R$ value of 0.955 indicates that the relationship of volunteer self-efficacy with knowledge of first aid, training and experience is very strong. R2 values show a value of $0.913(91.3 \%)$ which means that $91.3 \%$ of volunteers' self-efficacy in performing first aid for $\mathrm{KLL}$ victims is influenced by training and experience, while the remaining $8.7 \%$ is determined by other factors. The results of statistical tests show that the overall line equation is significant $(p=0,000 ; \alpha=0.05)$. The most dominant factor associated with voluntary selfefficacy in performing first aid for KLL victims was experience $(\beta=0.407)$.

\section{DISCUSSION OF RESULTS}

The Correlation Between Training with Self Efficcay. The results of this study correlate with research conducted by Ambarika (2017) on 32 ordinary people respondents with the results of the study that the training in the form of pre hospital care simulations was able to improve the self-efficacy of ordinary people in providing first aid to traffic accident victims with a $p$ value of 0.001 . Training with a combination of case simulation methods is able to stimulate respondents to think critically and creatively so that they can increase self- 
confidence and self-efficacy in conducting first aid to KLL victims. According to Schunk (2001), Jam said that training can improve self-efficacy and development of skills.

Training is one of the factors that can influence self-efficacy because it is part of the application of actions in the field. In training activities information is provided as well as skills that will affect the skills of someone in taking action. Effective training must be carried out with clear methods, target tools and implementation objectives. Mondi (2008) said that to be able to carry out training activities effectively is influenced by several factors including organizational support, commitment of participants and organizers, the ability of technology and learning styles or techniques for delivering material delivered during training. Meanwhile, according to Haywood (1992) the factors that influence the success of effective training include organizational support, commitment and strong trust in education, training and individual development, training must be in line with strategies and objectives, formulations and interpretations, participants are able to demonstrate material that submitted, arranging the objectives and expected results of the training and conducting evaluations and improvements.

The Correlation Between Experience with Self Efficcay. The results of this study correlate with research conducted by Johani, et al (2017) on parents in carrying out first aid measures for children with injuries. This research was conducted by analyzing the factors that influence self-efficacy. The results of the study show that training and experience are the factors that most significantly influence parents' self-efficacy in carrying out first aid to children with injuries. According to Notoadmojo (2012), experience is influenced by several factors, namely knowledge, education, age, socio-economic background, culture, physical environment, and work. In this study the supporting factors through the demographic data of the respondents studied included knowledge, education, age and occupation. In the research data obtained the average knowledge of respondents is 9 with good interpretation, the average education of volunteers has a high school education background (77.6\%), the average age of respondents is 35 years and the work of most respondents is non-health. Good knowledge possessed by volunteers can increase the confidence of volunteers in helping so that the experience they have will increase and increase.

\section{CONCLUSION}

The conclusion of this study is that there is a significant relationship between training, and experience with volunteer self-efficacy in carrying out first aid for traffic accident victims in Malang. Experience is the factor that most influences volunteers' self-efficacy in carrying out first aid for traffic accident victims in Malang.

\section{REFERENCES}

1. Alhejaili, A. S dan Alsubhi, S. A. (2016). Knowledge and Attitude of First Aid Skills among Health Science Students at Taibah University. Journal of General Practice 2016.

2. Arikunto. (2009). Manajemen Penelitian. Jakarta: Rineka Cipta.

3. Badan Nasional Penanggulangan Bencana (BNPB). (2011). Pedoman Relawan Penanggulangan Bencana No 17 tahun 2011.

4. Bakke, H.K., Steinvik, T., Eidissen, S.I., Gilbert, M dan Wisborg, T. (2015). Bystander first aid in trauma - prevalence and quality: a prospective observational study. Acta Anaesthesiologica Scandinavica. International Journal of Anaesthesiology and Intesive Care pain and Emergency Medicine. 59: 1187-1193. doi: 10.1111/aas.12561

5. Bandura, A. (1986). Social Foundations of Tought and Action: A Social Cognitive Theory. Prentice-Hall. Englewood Cliffs.

6. Bandura, A. (2013). Self Efficacy Theory.University of New England, Armidale, NSW, 2351.

7. Clary, E. Gil dan Synder, M. (2014). The Motivations to Volunteer: Theoretical and Practical Considerations. Journal of Current Directions in Psychological Science Volume 8 No 5. DOI: 10.1111/1467-8721.00037. 
8. Dahlan, M. Sopiyudin. (2015). Statistik Kedokteran dan Kesehatan. Jakarta: Epidemiologi Indonesia.

9. Departemen Perhubungan Republik Indonesia. (2011). Kecelakaan Lalu Lintas Tempati Urutan Ketiga Penyebab Kematian. Jakarta: Pusat Komunikasi Publik. http://dephub.go.id/

10. Departemen Perhubungan Republik Indonesia. (2016). Data Investigasi Kecelakaan Lalu Lintas Angkutan Jalan Tahun 2010-2016. http://knkt.dephub.go.id/

11. Desiani, S., Nuraeni, A., dan Priambodo, A.P. (2017). How Do Knowledge and Self Efficacy of InternshipNursing Students in Performing Cardiopulmonary Resuscitation. Belitung Nursing Journal Volume 3 No 5.

12. Feist, J. (2008). Theories of P prsonality. Boston: Mc Graw Hill.

13. Huang, L, dan Peng, N. (2014). Self Efficacy of First Aid for Home Accidents among Parents with 0 to 4 year Old Children at Metropolitan Community Health Center in Taiwan. Journal of Accident Analysis and Prevention. Volume 52: 182-187. https://doi.org/10.1016/j.aap.2012.12.002

14. IFRC. (2016). International First Aid and Resuscitation Guidelines 2016.

15. Judge, T.A. dan Bono, E. Joyce. (2001). Relationship of Core Self Evaluation Traits Self Esteem, Generalized Sef Efficacy, Locus of Control and Eotional Stabiity with Job Satisfaction and Job Performance: a meta analysis. Journal of Applied Psychology Volume 86 No 1: 80-92.

16. Kandakai, T dan King, K. (2013). Perceived Self Efficacy in Performing Lifesaving Skills: An Assesment of The American Red Cross's Respinding to Emergencies Course. Journal of Health Education Volume 30 Issue 4: 235-241.

17. Keech, P. (2006). First Aid Handbook Fast and Effective Emergency Care.

18. Kementerian Kesehatan Republik Indonesia. (2016). Kejadian Gawat Darurat Medik. http://www.depkes.go.id/

19. Kureckova, V., Gabrhel, V., Zamecnik ,P., Rezac, P., Zaoral, A dan Hobl, J. (2017). First Aid as an Important Traffic Safety Factor-Evaluation of The Experience-Based Training. Doi: 10.1007/s12544-016-0218-4.

20. Lenz, R. Elizbeth dan Bagget, S. (2002). Self Efficacy in Nursing Research and Measurement Perspective. New York: Springer Publishing Company.

21. Lojpur,M. (2010). First Aid to The Injured.

22. Margaretha. (2012). Buku Cerdas Pertolongan Pertama pada Kecelakaan. Yogyakarta: Niaga Swadaya.

23. Marsaid, Hidayat M, dan Ahsan. (2013). Faktor yang berhubungan dengan kejadian KLL pada pengendara sepeda motor di Wilayah Polres Malang. Jurnal IImu Keperawatan Vol 1 No 2 November2013.

24. Notoadmodjo, S. (2012). Promosi Kesehatan dan Perilaku Kesehatan. Jakarta: Rineka Cipta.

25. Paul, A., Hayes, J dan Woodman, R. (2007). First Aid and Harm Minimisation for Victims of Road Trauma: A Population Study. Final Report.

26. Peraturan Menteri Kesehatan Republik Indonesia No. 19 Tahun 2016 tentang Sistem Penanggulangan Gawat Darurat Terpadu. http://64696e6b6573.mi-kes.net/

27. Pusponegoro, D. A dan Sujudi, A. (2016). Kegawatdaruratan dan Bencana Solusi dan Petunjuk Teknis Penanggulangan Medik dan Kesehatan. Jakarta: Rayyana Komunikasindo.

28. Schwarzer, R dan Jerusalem, M. (1995). Generalized Self Efficacy Scale. Measures in Health Psychology: a user's portofolio. Causal and Control Beliefs. Windsor, UK: 35-37.

29. Schroeder, D.A., Penner, L.A., Dovidio, J.F dan Pillavin, J. A. (1995). The Psychology of Helping and Altruism. Problem and Puzzles. New York: Mc Graw-Hill.

30. Sharkasy, H., Shenouda, S., Sheikh, E., Gida, I dan Shahat, M. (2015). Impact of First Aid Training Program for Car Drivers about Road Traffic Injury in Port Sai. Medical Journal Cairo University, Vol 83 No, 2 December: 135-143.

31. Straubhaar dan Larose. (2004). Understanding Media, Culture and Technology. United States of America: Wadsworth. 
32. Suryanto., Boyle, M dan Plummer, V. (2017). The Prehospital and Healthcare system in Malang, Indonesia. Australian Journal of Paramedicine. Volume 14 Issue 2.

33. Sutarman. (2009). Pengantar Teknologi Informasi. Jakarta: Bumi Aksara.

34. Sutrisno. (2011). Manajemen Sumber Daya Manusia. Jakarta: Kencana.

35. Tannvik, T. D., Bakke, H. K., \& Wisborg, T. (2012). A systematic literature review on first aid provided by laypeople to trauma victims. Acta Anaesthesiologica Scandinavica, 56(10), 1222-1227.

36. Thygerson, A. L., Gulli, B. dan Piazza, G. M. (2012). First aid, CPR, and AED Standard. American College of Emergency Physicians and Emergency Care and Safety Institute.

37. Tobing, $\mathrm{N}$ dan Tehuteru. (2008). Peran Relawan dalam Memberikan Pendampingan kepada anak penderita kanker dan kelaurganya. Indonesian Journal of Cancer.

38. Tschirhart, M., Mesch, D.J., Perry, J.L., Miller, T.K dan Lee, G. (2001). Stipended Volunteers: Their Goals, experiences, satisfaction, and likehoold of future service. Non profit and voluntary sector quarterly, 30 (3), 422-443.

39. Wang, J., Wei, C., Harada, K., Minamoto, K., Ueda, K., Wei Cui, H., Zhang, C., Cui, Z., dan Ueda, A. (2010). Applying the Social Cognitive Perspective to Volunteer Intention in China: The Mediating Roles of Self Efficacy and Motivation. Health Promotion International Journal Vol. 26 No 2.

40. Whittaker, J dan Handmer, J. (2015). A review of Informal Volunteerismin Emergencies and Disaster: Definition, Opportunities and Challenges. International Journal of Disaster Risk Reduction Volume 13: 358-368.

41. Widodo. (2015). Manajemen Pengembangan Sumber Daya Manusia. Yogyakarta: Pustaka Pelajar.

42. World Health Organization (WHO). (2004). Road Traffoc Accidents in Developing Countries. Report of WHO meeting.

43. World Health Organization (WHO). (2005). Violence and Injury Prevention. PreHospital Trauma Care System. http://www.who.int/ 